\title{
Elektroničko nasilje među djecom i njegova usporedba s klasičnim oblicima vršnjačkog nasilja
}

\author{
Nives Strabić \\ Ana Tokić Milaković \\ Sveučilište u Zagrebu, Pravni fakultet, Studijski centar socijalnog rada
}

\begin{abstract}
Sažetak
Osim u klasične oblike nasilja (fizičko, verbalno, relacijsko, seksualno, ekonomsko i kulturalno), djeca su u novije vrijeme uključena u nasilnička ponašanja posredstvom elektroničkih medija. Ovaj rad donosi pregled literature koja se bavi nasiljem među djecom, s ciljem utvrđivanja sličnosti i specifičnosti elektroničkog nasilja u odnosu na klasične oblike. Sličnosti ovih oblika nasilničkog ponašanja među djecom se prvenstveno manifestiraju u preklapanju ključnih elemenata definicije zlostavljanja među djecom te povezanosti između činjenja elektroničkog i klasičnih oblika nasilja, odnosno povezanosti između doživljavanja obaju oblika nasilja. S druge strane, postoje stajališta da je elektroničko nasilje specifična pojava koja se od klasičnog nasilja među djecom razlikuje prema obilježjima ključnih elemenata definicije nasilničkog ponašanja, anonimnosti «počinitelja» nasilja, širine publike te visokoj dostupnosti nasilnih sadržaja u svakom trenutku. Također, u radu se uspoređuju čimbenici rizika i zaštite (na individualnoj, obiteljskoj, školskoj i vršnjačkoj razini) za uključenost djece u klasično i elektroničko nasilje. lako je pojavnost elektroničkog nasilja u svijetu i u Hrvatskoj još uvijek znatno niža od klasičnih oblika nasilja, zbog utvrđenih specifičnosti elektroničkog nasilja, važno je da aktualni programi prevencije nasilja među djecom implementiraju i određene aktivnosti ciljano usmjerene na smanjivanje elektroničkog nasilja među djecom.
\end{abstract}

Ključne riječi: nasilje među djecom, elektroničko nasilje, klasični oblici nasilja, čimbenici rizika i zaštite

\section{Uvod}

Već od ranog djetinjstva vršnjaci zauzimaju važnu ulogu u socio-emocionalnom razvoju osobe (Hepler, 1997). Tako se u interakciji s vršnjacima mogu razvijati socijalne vještine, pozitivni stavovi, prilagođena ponašanja te dobivati važan izvor socijalne podrške, no druženje s vršnjacima nerijetko uključuje i određene neželjene ishode, među kojima su i nasilna ponašanja među djecom. Određeno ponašanje djece može se smatrati vršnjačkim zlostavljanjem (eng. bullying) ako ono uključuje: (1) namjerno negativno postupanje, (2) nanošenje štete drugom djetetu, (3) obilježje opetovanosti te (4) prisutnosti neravnoteže snaga između djeteta koje čini i onog koje doživljava takvo ponašanje (Olweus, 1998). Međutim, nasilna ponašanja među djecom ne moraju nužno uključivati sve spomenute karakteristike, već djeca mogu činiti i doživljavati širi spektar nasilnih postupanja (Rajhvajn Bulat i Ajduković, 2012). Prema tome, nasilje među djecom (eng. peer violence) se smatra nadređenim i širim pojmom od vršnjačkog zlostavljanja te se može očitovati na različite načine ${ }^{12}$. Tako Milašin, Vranić i Buljubašić Kuzmanović (2009) razlikuju fizičko (npr. udaranje, guranje, pljuvanje), verbalno (zadirkivanje, nazivanje pogrdnim imenima itd.), relacijsko (očituje se isključivanjem iz društva i širenjem glasina o drugoj osobi), seksualno (npr. neželjeni fizički kontakti seksualnog

1 Unatoč čestom jednoznačnom korištenju termina nasilja i zlostavljanja među djecom u domaćoj i stranoj literaturi, u ovom tekstu će se koristiti oba termina kako ih navode autori izvornih radova, no nastojat će se uvažavati spomenuta razlika između njih (i kod klasičnog i elektroničkog modaliteta). 
karaktera), ekonomsko (poput otuđivanja i iznuđivanja novca) i kulturalno nasilje (poput vrijeđanja na nacionalnoj, religijskoj ili drugoj zabranjenoj osnovi). Pritom, prema vidljivosti nasilnih postupaka, spomenuti oblici klasičnog nasilja mogu biti otvoreni ili skriveni (Velki i Kuterovac Jagodić, 2014).

Zahvaljujući kontinuiranom napretku tehnologije šire se mogućnosti komunikacije i interakcije među djecom. lako elektronički mediji postaju izrazito popularni u toj populaciji, njihovo korištenje nosi određene rizike. Tako u virtualnoj sferi djeca i mladi mogu vrlo lako biti izloženi povredama svojih prava, primjerice prava na privatnost ili prava na zaštitu od potencijalno štetnih informacija i sadržaja (Pezo, 2010). Posredstvom elektroničkih medija svakodnevno nasilje među djecom širi se i na virtualni prostor kreirajući tzv. elektroničko nasilje. Elektroničko nasilje se može definirati kao namjerno i opetovano nasilno postupanje usmjereno djetetu putem računala, mobilnih uređaja i drugih informacijskih i komunikacijskih medija (Patchin i Hinduja, 2015).

Uključenost djece u virtualna nasilnička ponašanja se također manifestira na različite načine (Baum, 2007, Willard, 2007) kao što su: (1) uznemiravanje (eng. harassment), tj. ponavljano slanje uvredljivih i uznemiravajućih poruka te njihova objava na mjestima vidljivim široj «publici», (2) prijetnje na internetu (eng. cyberthreats) usmjerene drugoj osobi, skupinama ili samome sebi, (3) blaćenje (eng. denigration), tj. širenje neistinitih i štetnih informacija o osobi ili mijenjanje nečijih fotografija (s ciljem nanošenja štete ugledu osobe), (4) grubo online sukobljavanje (eng. flaming) koje uključuje izazivanje sukoba slanjem različitih uvredljivih ili vulgarnih poruka, (5) pretvaranje (eng. impersonation), odnosno dešifriranje lozinki različitih profila (npr. na društvenim mrežama) te korištenje tuđeg ili lažnog identiteta (u svrhu slanja ili objavljivanja kompromitirajućih sadržaja o drugima), (6) iznuđivanje i širenje povjerljivih informacija (eng. outing and trickery) koje izlaganjem postaju dostupne široj javnosti (s ciljem sramoćenja i blaćenja osobe), (7) isključivanje na internetu (eng. exclusion) koje se očituje zabranjivanjem pristupa osobi ili skupinama određenim web stranicama ili grupama na društvenim mrežama te namjernim isključivanjem osobe s različitih lista online prijatelja, (8) uhođenje na internetu (eng. cyberstalking), tj. opetovano slanje prijetećih ili uznemiravajućih poruka koje rezultiraju strahom osobe za vlastitu sigurnost.

S obzirom da je elektroničko nasilje relativno novi modalitet nasilja, stručna literatura nerijetko polazi od konteksta u kojem se odvijaju klasični oblici vršnjačkog nasilja, uz analiziranje posebnih karakteristika nasilnog ponašanja djece u virtualnoj sferi (Erdur-Baker, 2010.). U skladu s time, cilj ovog rada je usporediti elektroničko nasilje u odnosu na klasične oblike nasilja i to kroz prikaz konceptualne rasprave o njihovoj sličnosti i specifičnosti u suvremenoj stručnoj i znanstvenoj literaturi te uspoređujući njihovu prevalenciju, pojavne oblike i istraživane korelate (potencijalne rizične i zaštitne čimbenike).

\section{Konceptualna usporedba klasičnog i elektroničkog zlostavljanja i nasilja među djecom te njihova pojavnost}

Konsenzus o odnosu klasičnog i elektroničkog zlostavljanja i nasilja među djecom još uvijek nije u potpunosti postignut. Neki autori smatraju vršnjačko zlostavljanje jedinstvenim fenomenom (npr. Beran i Li, 2007, Mehari, Farell i Le, 2014), a nasilna ponašanja među djecom koja se odvijaju u virtualnom kontekstu tek nastavkom klasičnog nasilnog ponašanja, odnosno novim modalitetom iste pojave. Pritom se koriste elementima definicije klasičnog zlostavljanja kako bi definirali 
elektroničko zlostavljanje (Mehari i sur., 2014). Kako bi se ponašanje djece smatralo zlostavljanjem, bilo da se odvija u neposrednoj interakciji ili u virtualnom okruženju, važno je da uključuje opetovana agresivna postupanja s namjerom nanošenja štete pri čemu se javlja neravnoteža snaga između djeteta koje čini i onog koje doživljava takvo postupanje. Prema tome, obje pojave u određenoj mjeri zadovoljavaju temeljne kriterije definicije vršnjačkog zlostavljanja (Olweus, 1998). U tom smislu, elektroničko nasilje među djecom se može smatrati jednim od indirektnih oblika agresivnog postupanja koja se ne odvijaju u interakciji «licem u lice» (kao što je slučaj kod klasičnog relacijskog nasilja), već posredstvom elektroničkih medija (Beran i Li, 2007).

Nadalje, ekvivalentnost klasičnog i virtualnog nasilničkog ponašanja se očituje u sukladnosti uloga djece uključene u oba modaliteta nasilja (Li, 2005, Modecki i sur., 2014). Tako su djeca koja čine klasično nasilje sklona i nasilnom postupanju putem elektroničkih medija. Isto tako, djeca koja su izložena klasičnim oblicima nasilja od strane vršnjaka često doživljavaju i elektroničko nasilje. Mladi koji istovremeno čine i doživljavaju klasično vršnjačko nasilje, također vrše nasilna postupanja u virtualnom okruženju te su im ujedno i izloženi (Li, 2005). Slično kao i kod klasičnog nasilja kojem mogu svjedočiti vršnjaci, poruke ili komentari mogu biti predstavljeni u javnoj virtualnoj domeni i biti dostupni poznanicima ili nepoznatim osobama djeci uključenoj u nasilje. Drugim riječima, uloga „publike" u virtualnom prostoru je u određenoj mjeri usporediva s ulogom vršnjaka i prolaznika u školi ili na ulici (Beran i Li, 2007).

Drugi autori su manje skloni razmišljanju o vršnjačkom nasilju kao jedinstvenom fenomenu te prvenstveno ističu specifičnosti elektroničkog nasilja u odnosu na klasične oblike nasilja među djecom (npr. Dooley, Pyżalski i Cross, 2009, Slonje, Smith i Frisen, 2012). Tako Patchin i Hinduja (2015) problematiziraju spomenute elemente definicije zlostavljanja kada se ono odvija putem elektroničkih medija. Budući da je namjera «počinitelja» ključan element koji razlikuje zlostavljanje od slučajnih incidenata na internetu, ovu je komponentu upitno promatrati iz perspektive osobe koja doživljava nasilje. Naime, osoba će katkada percipirati da je nasilničko ponašanje kojem je izložena počinjeno s namjerom, čak i kada to u realnosti nije slučaj (Patchin i Hinduja, 2015). Primjerice, netko može komentirati sliku ili neki drugi sadržaj u šali, no zbog izostanka neverbalne komunikacije, osoba kojoj je namijenjen komentar to može doživjeti kao provokaciju ili uvredu.

Također, element štete kao posljedice elektroničkog zlostavljanja djece je ključan, ali ponekad manje očigledan i prepoznatljiv u virtualnom okruženju (Vandebosch i Van Cleemput, 2008). S obzirom da djeca sklona vršenju nasilja putem interneta ne vide osobu kojoj nanose štetu niti posljedice takvog ponašanja, Patchin i Hinduja (2015) drže kako nije opravdano nastalu štetu promatrati iz perspektive mladih koji se nasilnički ponašaju, jer su oni obično skloni racionalizaciji i umanjivanju posljedica svojih radnji.

Nadalje, zbog naravi virtualnog okruženja postoji izvjesna vjerojatnost opetovanosti nasilnih postupaka (Patchin i Hinduja, 2015). Pritom i samo jednokratna objava nasilnog sadržaja na internetu može doprinijeti ponovljenom doživljaju nasilja osobe koja mu je izložena i to svaki puta kada je online.

Posljednja komponenta zlostavljanja među djecom uključuje neravnotežu snaga, koja se kod klasičnog nasilništva očituje u fizičkoj, psihološkoj ili socijalnoj nadmoći djeteta sklonog nasilnom ponašanju u odnosu na ono kojem je takvo ponašanje usmjereno. Za razliku od toga, superiornost 
djeteta koje nasilno postupa putem elektroničkih medija proizlazi iz informatičkih znanja i vještina te posjedovanja ili dostupnosti sadržaja kojima je svrha nanošenje štete (Patchin i Hinduja, 2015). Tako se nadmoć djeteta u virtualnom okruženju može izraziti kroz kontroliranje tema u raspravama na internetu, izazivanje sukoba slanjem virtualnih poruka neprimjerenog sadržaja ili višim statusom u virtualnim zajednicama (Shariff i Gouin, 2006, Menesini i Nocentini, 2009).

Osim problematiziranja navedenih komponenti definicije zlostavljanja, neki autori ističu određene razlike između klasičnog i elektroničkog nasilja među djecom (npr. Heirman i Walrave, 2008). Kada se radi o klasičnim oblicima vršnjačkog nasilja, identitet djeteta koje čini nasilje je obično poznat vršnjaku kojem je takvo ponašanje usmjereno te drugim osobama koje se eventualno nalaze u blizini odvijanja agresivnih postupaka (Greene, 2006). Stoga postoji izvjesna mogućnost da se djetetu koje doživljava nasilje pruži pravovremena zaštita od strane drugih osoba koje svjedoče nasilnim incidentima. Zbog potencijalne anonimnosti interakcija u virtualnom kontekstu, identitet djeteta koje čini nasilje može ostati nepoznat i neotkriven djetetu kojem su agresivni postupci usmjereni. Slonje i suradnici (2012) navode kako djeca koja počine elektroničko nasilje, a nisu otkrivena niti suočena s posljedicama svog ponašanja, imaju tendenciju za nastavljanjem agresivnog postupanja. S druge strane, djetetu koje je izloženo virtualnom nasilju je otežano, a ponekad i nemoguće saznati zlostavlja li ga pojedinac ili više osoba, poznanik ili nepoznata osoba i sl., što povećava doživljaj emocionalnog stresa (Heirman i Walrave, 2008). Uz to, anonimnost «počinitelja» nasilja može voditi ograničenoj mogućnosti za pravovremenom i adekvatnom intervencijom odraslih osoba ili samog djeteta izloženog agresivnom ponašanju te prevenciju takvih postupaka ubuduće (Slonje i sur., 2012).

Nadalje, uloga "publike" koja svjedoči virtualnom nasilju je složenija u odnosu na onu kada je riječ o klasičnom nasilju (Slonje i sur., 2012). Naime, klasični oblici vršnjačkog nasilja mogu se odvijati bez prisutnosti «promatrača» ili pred relativno ograničenom skupinom djece koja neposredno svjedoče agresivnom ponašanju (Heirman i Walrave, 2008). Međutim, posredstvom informacijsko-komunikacijskih tehnologija, isti akti nasilja izvršeni od strane nekog djeteta u jednom trenutku (npr. objava kompromitirajućeg sadržaja na internetu) mogu biti bilo kada u kasnijem periodu ponovno pregledani, komentirani ili distribuirani od strane druge osobe koja je prethodno svjedočila takvom činu, čime ona također preuzima ulogu „počinitelja” elektroničkog nasilja (Slonje i sur., 2012).

Ako se promatra kontekst odvijanja nasilničkog ponašanja, klasično vršnjačko zlostavljanje se obično smatra problemom školskog okruženja koji se uglavnom odvija pred vršnjacima u školi ili na putu prema kući (Beran i Li, 2007). Također, kod klasičnih oblika vršnjačkog nasilja dijete je izloženo štetnim ponašanjima isključivo u trenutačnom prostornom i vremenskom okviru (Burton, Florell i Wygant, 2013). S druge strane, nasilna ponašanja u virtualnom okruženju uglavnom nadilaze kontekst škole i ulice (Greene, 2006). Takva nasilna postupanja odvijaju se bez fizičke interakcije, a mogu se očitovati u svakom trenutku te im je dijete kojima su usmjerena trajno izloženo (Heirman i Walrave, 2008, Burton i sur., 2013).

Kada je riječ o pojavnosti vršnjačkog nasilja, ono se općenito smatra relativno raširenom pojavom u društvu. Pritom, Wang, lannotti i Nansel (2009) navode da su mladi u Sjedinjenim Američkim Državama najviše uključeni u verbalno $(53,6 \%)$ i socijalno $(51,4 \%)$, zatim fizičko $(20,8$ 
\%) te elektroničko nasilje (13,6 \%). U Njemačkoj je također klasično vršnjačko nasilje zastupljenije u odnosu na elektroničko, u kojem sudjeluje oko 5 \% djece (Riebel, Jäger i Fischer, 2009). Shodno tome, Smith i suradnici (2008) ističu da u Engleskoj i dalje prednjači klasično nasilje među djecom, no primjetan je i porast slučajeva elektroničkog nasilja. Čini se da i na području Hrvatske klasično vršnjačko nasilje još uvijek prednjači nad nasiljem u virtualnoj sferi. Tako je, primjerice, u istraživanju provedenom na reprezentativnom uzorku učenika sedmih razreda u Hrvatskoj (Pećnik i Tokić, 2011), 73\% sudionika izjavilo da su u proteklih godinu dana vršili pojedine oblike fizičkog nasilja (udaranje ili šamaranje), oko $50 \%$ njih je vršilo verbalno (psovanje i vrijeđanje) i relacijsko nasilje (širenje glasina), dok je oko $20 \%$ djece počinilo neke pojavne oblike elektroničkog nasilja (ugrožavanje ugleda putem interneta).

\section{Rizični i zaštitni čimbenici uključenosti djece u klasično i elektroničko nasilje}

Dugotrajna uključenost u vršnjačko nasilje može rezultirati štetnim učincima za cjelokupno funkcioniranje pojedinca. Isto tako, određena obilježja pojedinca mogu djelovati kao čimbenici rizika i/ili zaštite za uključenost djece u nasilna ponašanja. U nastavku će biti analizirani individualni, obiteljski, obrazovni i vršnjački čimbenici rizika i zaštite ${ }^{23}$. Čimbenici rizika, tj. čimbenici koji povećavaju vjerojatnost uključenosti djece u nasilje, nalaze se u složenom međuodnosu s unutarnjim i vanjskim snagama djeteta koje ublažavaju rizike i djeluju kao zaštitni čimbenici (Lösel i Farrington, 2012).

\subsection{Individualni čimbenici rizika i zaštite}

U domeni individualnih čimbenika jedno od najčešće proučavanih obilježja djece uključene u nasilje je spol djeteta. Pritom se navodi da dječaci češće čine klasične oblike nasilja u odnosu na djevojčice (Olweus, 1998, Erdur-Baker, 2010). Primjerice, Khamis (2015) utvrđuje da se klasičnim nasilnim postupanjima prema vršnjacima koristilo 21,5 \% dječaka u usporedbi s 14,2 \% djevojčica u protekla dva mjeseca. Moguću iznimku predstavlja vršenje relacijskog nasilja (Pećnik i Tokić, 2011), iako pojedini nalazi sugeriraju da se dječaci u približno sličnoj mjeri kao i djevojčice koriste relacijskom agresijom (Delveaux i Daniels, 2000). Kada je riječ o doživljavanju nasilja, smatra se da su dječaci u većem riziku u odnosu na djevojčice (Erdur-Baker, 2010, Griezel i sur., 2012). Tu tvrdnju ilustriraju rezultati spomenutog istraživanja (Khamis, 2015) koji pokazuju kako su u razdoblju od protekla dva mjeseca klasičnom nasilju vršnjaka nešto češće bili izloženi dječaci (21,8 \%) od djevojčica (18,0 \%). Nalaz o postojećim spolnim razlikama u doživljavanju vršnjačkog nasilja potvrđuju Silva i suradnici (2013), navodeći da su dječaci češće «žrtve» svih oblika klasičnog nasilja, osim relacijskog u kojem prednjače djevojčice.

Kada je u pitanju vršenje elektroničkog nasilja, neki autori smatraju da su dječaci i u virtualnom okruženju skloniji činiti nasilje od djevojčica (Li, 2006, Erdur-Baker, 2010, Wang i sur., 2009). Također, neka novija istraživanja utvrđuju postojanje spolnih razlika u činjenju elektroničkog nasilja u korist dječaka (Deniz, 2015). S druge strane, neki autori ne utvrđuju spolne razlike u počinjenju virtualnog nasilja te navode kako dječaci i djevojčice gotovo podjednako nasilno postupaju prema drugoj djeci (Slonje i Smith, 2008, Beckman, Hagquist i Hellström, 2013). Postoje i razmišljanja

2 Važni su također čimbenici koji djeluju na društvenoj razini (primjerice, šira okolina koja prezentira nasilje kao općeprihvaćen obrazac ponašanja može predstavljati rizičan čimbenik uključenosti djece u nasilje), no ovim radom neće biti obuhvaćeni. 
pojedinih autora da su djevojčice češće od dječaka uključene u nasilne postupke na internetu, što objašnjavaju sklonošću djevojčica za činjenjem posrednih oblika nasilja (Kowalski i Limber, 2007). Rezultati nisu konzistentni ni za doživljavanje virtualnog nasilja. Naime, neki autori navode da su dječaci (kao i kod klasičnih oblika nasilnog ponašanja) češće od djevojčica izloženi elektroničkom nasilju (Erdur-Baker, 2010, Deniz, 2015, Wong, Chan i Cheng, 2014). S druge strane, postoje i istraživanja koja ne pronalaze spolne razlike te sugeriraju da su dječaci i djevojčice u približno jednakom riziku od doživljavanja elektroničkog nasilja (Li, 2006), odnosno da se čak djevojčice češće nalaze u ulozi «žrtve» elektroničkog nasilja (Slonje i sur., 2012, Beckman i sur., 2013, Wang i sur., 2009). Budući da postoje oprečni nalazi, pojedini autori sugeriraju da je spol manje relevantan prediktor uključenosti djece u nasilje koje se odvija putem elektroničkih medija (García Fernández, Romera Félix i Ortega Ruiz, 2015). Također je moguće da su dječaci skloniji pojedinim oblicima nasilja u virtualnom okruženju (npr. grubom online sukobljavanju), dok za djevojčice mogu biti karakterističniji neki drugi oblici (npr. iznuđivanje i širenje informacija), no ove je hipoteze potrebno empirijski provjeriti.

Razmatrajući tjelesni izgled djeteta, ističe se da djeca koja su tjelesno snažnija od ostalih (Olweus, 1998) te djeca s povećanom tjelesnom težinom i pretilošću (Kukaswadia, 2009) češće čine klasične oblike nasilja. Sukladno tome, Janssen i suradnici (2004) utvrđuju kako klasično nasilje nešto češće vrše djeca s prekomjernom tjelesnom težinom (11,2\%) i pretilošću $(9,2 \%)$ nego djeca idealne tjelesne težine s obzirom na omjer visine i težine pojedinca ( $8,3 \%$ ). S druge strane, u riziku od doživljavanja nasilja su obično djeca slabije tjelesne građe od druge djece (Olweus, 1998), kao i djeca s prekomjernom tjelesnom težinom te pretilošću (DeSmet i sur., 2014). Primjerice, uspoređivanjem skupina djece prema tjelesnoj masi, istraživanje Janssen i suradnika (2004) pokazuje kako su klasičnim oblicima vršnjačkog nasilja češće izložena djeca povećane tjelesne težine $(14,4$ \%) i pretila djeca (18,5 \%) nego djeca idealne tjelesne težine (10,7 \%). Osim težine, mladi su često izloženi vršnjačkom nasilju zbog izgleda svojih zubi (Al-Bitar i sur., 2013) te različitih bolesti kože, poput akni ili dermatitisa (Magin, 2013).

Uzimajući u obzir karakteristike tjelesnog izgleda u slučaju elektroničkog nasilja, mladi koji nasilno postupaju u virtualnoj sferi ne moraju nužno biti fizički snažniji ili privlačniji u odnosu na svoje vršnjake. Ako čine virtualno nasilje «na račun» tjelesnog izgleda, usmjeravaju se na djecu koja su drugačija zato što nose specifičnu odjeću, naočale ili se ističu na drugi način (Berne, Frisén i Kling, 2014). Cassidy, Jackson i Brown (2009) navode da djeca često doživljavaju elektroničko nasilje na temelju tjelesne težine, stvarne ili percipirane seksualne orijentacije te stila odijevanja. Pritom su djevojčice dominantno izložene uvredljivim komentarima na internetu «na račun» prekomjerne tjelesne težine i tjelesne građe, odjeće ili šminke, a dječaci zbog naglašenih femininih karakteristika, stila odijevanja i fizičkog izgleda, pri čemu se često spominje homoseksualna orijentacija ili manja mišićna masa (Frisén i Berne, 2014, Berne i sur., 2014).

Što se tiče razvojnih specifičnosti, djeca s određenim teškoćama u razvoju će u stanju frustracije vjerojatnije reagirati nasilno prema svojim vršnjacima. Tako neki autori navode da su djeca s dijagnosticiranim poremećajem hiperaktivnosti i deficita pažnje (u nastavku: ADHD) sklona vršenju klasičnog nasilja (Taylor i sur., 2010). Konzistentno tome, Holmberg i Hjern (2008) navode da klasične oblike vršnjačkog nasilja znatno češće čine djeca koja pokazuju simptome ADHD-a (20,8 $\%)$ od djece bez dijagnosticirane razvojne teškoće $(7,0 \%)$. Istraživanja također pokazuju kako 
djeca s ADHD-om (Olweus, 1998), ali i djeca s teškoćama iz autističnog spektra (Schroeder i sur., 2014) i nekim drugim teškoćama u razvoju pripadaju rizičnim skupinama za doživljavanje nasilnih ponašanja od strane vršnjaka. Holmberg i Hjern (2008) su, primjerice, proučavanjem izloženosti djece klasičnom vršnjačkom nasilju s obzirom na prisutnost simptoma ADHD-a utvrdili kako je povremenom nasilju bilo izloženo mnogo više djece sa simptomima ADHD-a (32,5\%) nego djece bez razvojnih odstupanja (15,0 \%), a razlike su još uočljivije kada se radilo o čestom doživljavanju nasilja (2,0 \% djece bez i 31,8 \% djece sa simptomima ADHD-a).

Kao i klasično nasilje, djeca s ADHD-om nerijetko čine nasilje i u virtualnom okruženju (Yen i sur., 2014). Također, djeca s pojedinim intelektualnim teškoćama sklona su nasilnim aktivnostima na internetu (Didden i sur., 2009). Tako su Heiman i Olenik-Shemesh (2015) uspoređivanjem skupina djece prema razvojnom stupnju pronašli da u odnosu na djecu bez odstupanja u razvoju $(8,7$ \%), elektroničko nasilje nešto češće čine djeca s teškoćama u razvoju uključena u redoviti školski program (12,1\%), a još češće djeca s razvojnim teškoćama koja pohađaju nastavu u posebnim razrednim odjeljenjima (20,7 \%). Slično kao kod klasičnih oblika nasilja, djeca s ADHD-om te djeca s poremećajima iz autističnog spektra češće doživljavaju virtualno nasilje (Good i Fang, 2015). Također, elektroničkom nasilju su često izložena i djeca s teškoćama u učenju (Eden, Heiman i Olenik-Shemesh, 2013). Ukupno gledajući, čini se da određene specifičnosti u dječjem razvoju predstavljaju relevantne prediktore sudjelovanja djece u nasilnim ponašanjima, neovisno o modalitetu nasilja.

Nakon izloženih rizičnih čimbenika, valja napomenuti da su čimbenici zaštite koji djetetu olakšavaju nošenje s rizikom uključenosti u vršnjačko nasilje viši stupanj inteligencije, visoka razina prosocijalnog ponašanja, kao i odsutnost simptoma ADHD-a te dječje depresivnosti i anksioznosti (Lösel i Bender, 2013). Također, Wachs (2012) naglašava kako smanjenju činjenja klasičnog i elektroničkog nasilja među djecom pridonose ponajprije razvoj empatije i smanjenje moralne distance od «žrtve» nasilja. Uz navedeno, više samopouzdanje djeteta, razvijene vještine konstruktivnog rješavanja sukoba i niži doživljaj socijalne izoliranosti pomažu djeci izloženoj nasilju vršnjaka u suočavanju s agresivnim postupcima (Sapouna i Wolke, 2013). Nadalje, visoka razina emocionalne kontrole koja podrazumijeva sposobnost djeteta da se suzdrži od negativnih reakcija (npr. ljutnje, straha ili tuge) na doživljeno nasilje, pokazala se važnim zaštitnim čimbenikom kod izloženosti djeteta klasičnom i virtualnom nasilju od strane druge djece (Hemphill i sur., 2014). Kada je riječ o elektroničkom nasilju specifično, izbjegavanje susreta s nepoznatim osobama koje su djeca upoznala na internetu pridonosi zaštiti djece i sprječavanju njihovog sudjelovanja u nasilju u virtualnom kontekstu (Wachs, Wolf i Pan, 2012). Uz to, Vandebosch, Poels i Deboutte (2014) navode kako je informiranost djece o važnosti adekvatnih načina reagiranja na doživljeno elektroničko nasilje (npr. odabir postavki zaštite privatnosti, čuvanje dokaza i povjeravanje odraslim osobama o doživljenom nasilju) iznimno važno u situacijama njihove izloženosti nasilnim ponašanjima.

\section{2. Čimbenici rizika i zaštite u obiteljskom okruženju}

Osim osobnih, važne prediktore nasilja među mladima predstavljaju čimbenici u obiteljskom okruženju djeteta, posebice kvaliteta odnosa s roditeljima. Pritom se u vezu s činjenjem klasičnog vršnjačkog nasilja dovodi odrastanje u obiteljima s izraženim i čestim sukobima među članovima, ali i onima pretjerano zaštićujućima (Figula i sur., 2011), kao i izloženost djeteta autoritarnom 
odgojnom stilu roditeljstva koji je rigidan i krut te bez adekvatne razine responzivnosti i podrške (Georgiou i sur., 2013). S druge strane, izloženost djece psihološkoj agresivnosti (Gómez-Ortiz, Romera i Ortega-Ruiz, 2015) ili zlostavljanju i zanemarivanju od strane roditelja (skrbnika) je povezana s doživljavanjem nasilja i od strane vršnjaka u školi (Boel-Studt i Renner, 2014). Također, djeca čije roditelje karakterizira popustljiv odgojni stil su u nešto većem riziku od izloženosti nasilju druge djece (Georgiou, 2008).

Kada je riječ o vršenju elektroničkog nasilja, nedostaci ili izbjegavanje komunikacije između djeteta i roditelja te općenito unutar obitelji povezuju se s djetetovom sklonosti za nasilnim ponašanjem u virtualnom okruženju (Floros i sur., 2013). Kao i kod klasičnih oblika nasilja, autoritarni odgojni stil je povezan s vršenjem nasilja putem elektroničkih medija (Floros i sur., 2013). Nadalje, pokazalo se da su učestalo kažnjavanje djece ili pretjerana popustljivost roditelja prediktori činjenja, ali i doživljavanja elektroničkog nasilja među vršnjacima (Velki i Kuterovac Jagodić, 2014). Makri-Botsari i Karagianni (2014) pronalaze da su autoritaran i zanemarujući odgojni stil roditelja u usporedbi s popustljivim ili autoritativnim, povezani s povećanom vjerojatnošću od izloženosti djece virtualnom nasilju, što je u skladu s nalazom da je niža responzivnost roditelja povezana s doživljavanjem elektroničkog nasilja (Dehue i sur., 2012).

Što se tiče čimbenika zaštite u obiteljskom okruženju, snažna povezanost s članovima obitelji i otvorena komunikacija o problemima djece povezuju se s djetetovim rjeđim činjenjem nasilja i većom vjerojatnosti da će dijete sklono nasilnom postupanju s vremenom promijeniti svoje ponašanje (Duggins i sur., 2016). Uz navedeno, konzistentni roditeljski postupci (Lösel i Bender, 2013) i roditeljska toplina (Karlsson i sur., 2014, Dehue i sur., 2012) predstavljaju zaštitne čimbenike od činjenja i doživljavanja nasilja među djecom. Također, uvažavanje djetetovog mišljenja u skladu s njegovom dobi i zrelosti, razmjena ideja između roditelja i djece te upoznatost roditelja s djetetovim prijateljima smanjuju vjerojatnost uključenosti djece u klasično i elektroničko nasilje (Shetgiri, Lin i Flores, 2013). Nadalje, naglašen doživljaj povezanosti s roditeljima pomaže djeci izloženoj nasilju vršnjaka da se s iskustvom doživljenog nasilja nose na konstruktivan način (Duggins i sur., 2016), prvenstveno povjeravanjem roditeljima (Hemphill i sur., 2014). Osim toga, dostupnost podrške unutar obitelji može voditi smanjenom riziku od doživljavanja virtualnog nasilja, posebno u slučaju izostanka podrške prijatelja (Fanti, Demetriou i Hawa, 2012).

U literaturi koja povezuje roditeljske postupke i rizičnost za sudjelovanje djece u virtualnim oblicima nasilja često se ističe i važnost adekvatnog roditeljskog nadzora, posebice tijekom adolescencije kada roditelji sustavno sve manje nadziru djetetovo korištenje interneta (Krmek, Buljan Flander i Hrpka, 2007). Tako su You, Kim i Kim (2014) pronašli povezanost između neadekvatne razine roditeljskog nadzora i tendencije adolescenata da se nasilnički ponašaju prema drugima u virtualnom okruženju. Ističe se i to da relativno mali broj roditelja postavlja filtere ili programe za sigurno korištenje interneta u svrhu zaštite djece (Levine, 2013). Osim toga, čini se i da roditelji sustavno precjenjuju razinu svog nadzora nad upotrebom interneta njihove djece. Tako Wang, Bianchi i Raley (2005) navode da svega 61 \% roditelja izjavljuje da u njihovoj obitelji postoje jasna pravila oko korištenja interneta, od kojih je čak trećina opovrgnuta izjavama njihovih adolescenata kako takva pravila ne postoje. Također, u posljednje vrijeme način mjerenja roditeljskog nadzora u istraživanjima doveden je u pitanje (Stattin i Kerr, 2000), jer su postojeće skale nadzora zapravo mjerile roditeljsko znanje o tome što dijete radi kada je izvan vidokruga roditelja. Stattin i Kerr 
(2000) su pokazali da je to znanje u najvećoj mjeri stečeno slobodnim i spontanim samootkrivanjem djeteta, a ne roditeljskim kontrolirajućim postupcima i nadzorom (Stattin i Kerr, 2000). U skladu s time, pronađeno je da aktivne roditeljske strategije nadzora nad korištenjem elektroničkih medija (poput sjedenja za kompjuterom uz adolescenta, provjeravanja posjećenih internetskih stranica i korištenja sigurnosnih filtera) zapravo nisu povezane $s$ uključivanjem djeteta u različita rizična ponašanja putem interneta (za pregled vidjeti Liau, Khoo i Ang, 2008). Ako kod kuće postoje pretjerano restriktivna pravila i nadzor oko korištenja interneta, vrlo je vjerojatno da će adolescenti pristupiti internetu s drugih mjesta kao što je dom prijatelja ili kafić s pristupom internetu (Khoo i sur., 2006, prema Liau i sur., 2008). Prema tome, umjesto direktnog roditeljskog nadzora mnogo je važnije unaprijediti i njegovati otvorenu komunikaciju s adolescentima o korištenju interneta (Liau i sur., 2008).

\section{3. Čimbenici rizika i zaštite u školskom i vršnjačkom okruženju}

Uz spomenute dispozicije djeteta te karakteristike obiteljskog okruženja, različiti čimbenici u kontekstu škole mogu pridonijeti sudjelovanju djece u nasilničkom ponašanju. Kada je riječ o povezanosti školskog postignuća i vršenja klasičnih oblika nasilja, pokazalo se da su slabiji školski uspjeh učenika (Ma i sur., 2009, Bradshaw i sur., 2013, Kowalski i Limber, 2013) i negativna percepcija vlastite akademske kompetencije (Ma i sur., 2009) povezani s nasilničkim postupanjem. S druge strane, djeca koja postižu bolje školske rezultate u odnosu na druge učenike češće doživljavaju vršnjačko nasilje, vjerojatno zbog zavisti drugih učenika u pogledu školskog uspjeha (van der Werf, 2014). Pritom izloženost nasilničkom ponašanju obično s vremenom dovodi do slabljenja školskog postignuća (Espelage i sur., 2013, van der Werf, 2014).

Kao i u slučaju klasičnog nasilja, djeca koja koriste nasilničke obrasce ponašanja na internetu u usporedbi sa svojim vršnjacima obično postižu slabije rezultate u školi (Kowalski i Limber, 2013, Selak Bagarić i sur., 2014). U skladu s time, Mitchell (2011) je pokazala da će djeca s višim školskim postignućem vjerojatno u manjoj mjeri vršiti nasilje putem elektroničkih medija, ali su i rjeđe izložena istom. Također, niže akademsko postignuće se obično povezuje i s postajanjem «žrtve» elektroničkog nasilja (Twyman i sur., 2010). Naime, Beran i Li (2007) objašnjavaju da poteškoće u izvršavanju školskih obaveza vode povećanoj izloženosti zadirkivanju, ismijavanju i drugim nasilnim postupcima djece, kako u školi tako i putem elektroničkih medija. Međutim, niže akademsko postignuće djeteta može se javiti i kao posljedica doživljavanja virtualnog nasilja (Ryan i Curwen, 2013).

Slaba privrženost školi također predstavlja čimbenik rizika za djecu koja čine nasilje prema vršnjacima u školi. Naime, Swearer (2002, prema Alika, 2012) navodi da su mladi koji čine nasilje skloni različitim rizičnim aktivnostima (npr. izbjegavanju nastave) koje posredno mogu voditi napuštanju obrazovanja. Također, izbjegavanje škole i u konačnici ispadanje iz sustava obrazovanja je povezano i s doživljavanjem nasilja u školi (Alika, 2012).

U skladu s nalazima u domeni vršenja klasičnih oblika nasilja, izostanci iz škole te njeno prerano napuštanje zbog zdravstvenih razloga ili ocjena povezani su s nasilnim postupanjem mladih u virtualnoj sferi (Kowalski i Limber, 2013). Također, djeca koja su dugotrajno izložena elektroničkom nasilju u većoj mjeri odbijaju odlaziti u školu u usporedbi s djecom koja ga ne doživljavaju (Pregrad i sur., 2010). 
Vezano uz odnose s vršnjacima, Velki i Vrdoljak (2013) ističu da djeca sklona nasilnom postupanju imaju veći broj prijatelja, iako često nisu omiljena u društvu. Osim toga, obično se druže s vršnjacima koji potiču njihovo agresivno ponašanje. Nadalje, slabija socijalna prilagodba djeteta u vršnjačkom kontekstu predstavlja rizičan čimbenik za činjenje, ali i doživljavanje klasičnih oblika nasilja među djecom (García Fernández i sur., 2015).

Što se tiče elektroničkog nasilja, utvrđeno je da vršnjaci koji toleriraju nasilno reagiranje pridonose sklonosti djeteta da jednako postupa i u virtualnoj sferi (Festl, Scharkow i Quandt, 2013). Slično tome, prijatelji u virtualnom okruženju (npr. na društvenim mrežama) vrlo lako mogu preuzeti ulogu «promatrača» elektroničkog nasilja, a njihovo poticanje ili podržavanje nasilnih postupanja na internetu mogu pridonijeti online nasilnom ponašanju (Dodge i sur., 2006, prema Hemphill i Heerde, 2014). Slično klasičnom nasilju, slabija kvaliteta odnosa s vršnjacima vodi većoj vjerojatnosti za izloženost elektroničkom nasilju (Slonje i Smith, 2008). Ipak, neka novija istraživanja nisu utvrdila da je slabija socijalna prilagodba djeteta u kontekstu vršnjaka prediktor činjenja virtualnog nasilnog ponašanja (García Fernández i sur., 2015). Uz to, djeca s većim brojem prijatelja na Facebooku koji redovito distribuiraju objave negativnog sadržaja su i sama u povećanom riziku od doživljavanja virtualnog nasilja (Peluchette i sur., 2015).

Razmatrajući zaštitne čimbenike u školskom i vršnjačkom kontekstu, Puzić, Baranović i Doolan (2011) navode da primjeren nadzor učitelja i drugih suradnika škole predstavlja važan izvor podrške učenicima u rješavanju sukoba. Oslanjajući se na spomenute rezultate istraživanja u području roditeljskog nadzora i prilagodbe adolescenata (Stattin i Kerr, 2000), treba istaknuti kako je i ovdje poželjno nadzor temeljiti na otvorenoj i dvosmjernoj komunikaciji te uspostavljanju kvalitetnog odnosa između nastavnika i učenika. Smanjenju uključenosti djece u nasilna ponašanja također pridonose jasna pravila u razredu i podržavajuća klima, edukacija nastavnika o važnosti prevencije nasilja, redovita komunikacija između nastavnika i roditelja te timski oblik rada učenika (Ttofi i Farrington, 2011). Uz to, snažan doživljaj pripadnosti školi može pomoći djetetu da na doživljeno nasilje ne reagira agresivnim postupcima već konstruktivnim rješavanjem sukoba (Duggins i sur., 2016). Također, kvalitetna nastava, praćenje izvršavanja školskih zadaća i ponašanja te briga za učenike od strane njihovih nastavnika pridonose smanjenoj uključenosti djece u vršnjačko nasilje (Karlsson i sur., 2014). Nadalje, podržavajuća školska klima povećava spremnost djece na uključivanje u programe prevencije nasilja te ih potiče na obraćanje odraslima u slučaju sudjelovanja u istom (Selak Bagarić i sur., 2014).

\section{Zaključak}

Na pitanje je li elektroničko nasilje tek jedan od oblika klasičnog vršnjačkog nasilja ili je novi fenomen nije moguće dati jednoznačan odgovor, no pregled provedenih istraživanja koja uspoređuju ove oblike nasilja među djecom ukazuje na određene sličnosti elektroničkog nasilja s klasičnim oblicima nasilja, ali i stanovite specifičnosti.

Prije svega, na sličnost ovih oblika nasilničkog ponašanja među djecom ukazuje preklapanje ključnih elemenata definicije, pri čemu zlostavljanje (bilo izravno ili posredstvom elektroničkih medija) uključuje opetovana nasilna ponašanja počinjena s namjerom nanošenja štete uz nerazmjer moći između djeteta koje čini i doživljava takvo postupanje (Mehari i sur., 2014). Uz to, neki autori 
navode kako se kontekst odvijanja klasičnog i elektroničkog nasilja ne razlikuje, već je nasilje u virtualnoj sferi dodatni modalitet indirektnog vršnjačkog nasilja (Beran i Li, 2007). Također, sličnost ovih pojava se očituje u korelaciji između činjenja elektroničkog i klasičnog nasilja te između doživljavanja oba oblika nasilja (Modecki i sur., 2014), što znači da vrlo često isti pojedinci čine, odnosno doživljavaju oba oblika nasilja. Nadalje, određene individualne karakteristike djeteta su dosljedno zaštitni/rizični čimbenici za pojavu klasičnih oblika i elektroničkog nasilja. Tako su djeca s prekomjernom tjelesnom težinom i pretilošću (DeSmet i sur., 2014, Berne i sur., 2014) te djeca s teškoćama iz autističnog spektra (Schroeder i sur., 2014, Good i Fang, 2015) u riziku od doživljavanja nasilja neovisno o modalitetu, dok su djeca s ADHD-om sklona vršenju i doživljavanju oba oblika nasilja (Taylor i sur., 2010, Yen i sur., 2014). S druge strane, zaštitnim čimbenicima od činjenja klasičnih oblika vršnjačkog i elektroničkog nasilja među djecom pokazali su se razvijena empatija te smanjenje moralne distance od "mete" nasilja (Wachs, 2012), dok je visoka emocionalna kontrola relevantan zaštitni čimbenik od doživljavanja oba modaliteta nasilja (Hemphill i sur., 2014). Dok se autoritaran odgojni stil roditeljstva pokazao važnim prediktorom činjenja klasičnog i elektroničkog nasilja (Georgiou i sur., 2013, Floros i sur., 2013), a doživljavanje nasilja se kod obje pojave vezuje uz iskustvo zanemarivanja od strane roditelja (Boel-Studt i Reiner, 2014, Makri-Botsari i Karagianni, 2014), kao važni zaštitni čimbenici od sudjelovanja djece u oba modaliteta nasilja navode se otvorena i dvosmjerna komunikacija u obitelji te upoznatost roditelja s djetetovim društvom (Shetgiri i sur., 2013). Razmatrajući školske i vršnjačke čimbenike, djeca koja čine klasično i elektroničko nasilje imaju slabije školsko postignuće (Bradshaw i sur., 2013, Kowalski i Limber, 2013), slabiju privrženost školi (Alika, 2012, Kowalski i Limber, 2013) te prijatelje koji potiču agresivno ponašanje (Velki i Vrdoljak, 2013, Festl i sur., 2013), a djeca sa slabijom kvalitetom odnosa s prijateljima su u riziku od izloženosti vršnjačkom nasilju (Slonje i Smith, 2008). Također, ukoliko u razredu vlada klima nasilnog reagiranja, ona će se prenijeti i u virtualnu domenu (Festl i sur., 2013). Suprotno tome, podržavajuća školska klima je ključan zaštitni čimbenik od uključenosti djece u nasilna ponašanja, neovisno o modalitetu nasilja (Ttofi i Farrington, 2011, Selak Bagarić i sur., 2014).

Unatoč utvrđenim sličnostima, neki autori naglašavaju specifičnosti elektroničkog nasilja i ističu da se u određenim aspektima razlikuje od klasičnih oblika nasilja. Tako Patchin i Hinduja (2015) smatraju da se ključne karakteristike zlostavljanja (namjera, opetovanost, šteta, neravnoteža snaga) različito očituju kada je riječ o klasičnom i kada se radi o elektroničkom nasilničkom ponašanju među djecom. Nadalje, anonimnost «počinitelja», «masovna» publika te dostupnost štetnih sadržaja svima i u svakom trenutku su obilježja koja su specifična za elektroničko nasilje te ga odvajaju od klasičnog vršnjačkog nasilja (Heirman i Walrave., 2008). Uz to, sudjelovanje djece u klasičnim oblicima vršnjačkog nasilja je vezano uz konkretan vremenski i prostorni kontekst (Burton i sur., 2013), dok ih virtualno nasilje nadilazi te se može očitovati u bilo kojem periodu (Greene, 2006). Istraživanja u Hrvatskoj i svijetu sugeriraju da je elektroničko nasilje još uvijek manje zastupljeno u odnosu na klasične oblike nasilja među djecom (npr. Pećnik i Tokić, 2011, Riebel i sur., 2009). Što se tiče individualnih čimbenika koji pridonose uključenosti djece u nasilje, pokazalo se da dječaci češće čine (Khamis, 2015, Deniz, 2015) i doživljavaju klasično vršnjačko nasilje nego djevojčice (Griezel i sur., 2012, Deniz, 2015), osim kada se radi o relacijskom nasilju. Kada je riječ o elektroničkom nasilju nalazi su prilično nekonzistentni, što može ukazivati na potrebu da se uzmu u obzir različiti pojavni oblici nasilja u virtualnom okruženju (npr. grubo online sukobljavanje može biti karakterističnije za dječake, a iznuđivanje i širenje informacija za djevojčice). Što se tiče tjelesnog 
izgleda, djeca koja čine klasične oblike nasilja su obično snažnije tjelesne građe (Olweus, 1998), što ne mora vrijediti za elektroničko nasilje (Berne i sur., 2014) kod kojeg se nadmoć djeteta koje čini nasilje, u odnosu na onog koje ga doživljava, očituje u posjedovanju informatičkih znanja, vještina ili dostupnosti kompromitirajućeg sadržaja i sl. (Patchin i Hinduja, 2015). Razmatrajući čimbenike vezane uz kontekst škole, djeca s boljim školskim postignućem su u nešto većem riziku od doživljavanja klasičnog nasilja (van der Werf, 2014), a ona sa slabijim rezultatima u školi često doživljavaju virtualno nasilje (Beran i Li, 2007). Uz to, slabija socijalna prilagodba djece u vršnjački kontekst je povezana s činjenjem klasičnog nasilja, no ne i s vršenjem elektroničkog nasilja među djecom (García Fernández i sur., 2015).

S obzirom na utvrđene dodirne točke između klasičnog nasilja među djecom i sveprisutnijeg elektroničkog nasilja, moguće je pretpostaviti da će postojeće metode prevencije vršnjačkog nasilja koje su implementirane u mnogim školama (za pregled vidjeti Velki i Ozdanovac, 2014) imati određeni učinak i na suzbijanje elektroničkog nasilja. Međutim, istaknute specifičnosti virtualnog nasilja ukazuju na potrebu posebnog posvećivanja pažnje tom obliku nasilja te uključivanje specifičnih mjera u postojeće programe, koje bi imale za cilj suzbijanje nasilja koje se događa izvan uobičajenih prostorno-vremenskih okvira u kojima se odvija klasično nasilje među djecom. Pritom je ključno podizanje svijesti šire javnosti o pojavnosti te vrste nasilja, konstantno profesionalno usavršavanje stručnjaka za rad s djecom (posebice u školama, ali i ostalim relevantnim ustanovama za djecu), adekvatna suradnja nadležnih službi te aktivno uključivanje djece i njihovih roditelja/ skrbnika u svim fazama prevencije.

\section{Literatura}

Al-Bitar, Z. B., Al-Omari, I. K., Sonbol, H. N., Al-Ahmad, H. T., Cunningham, S. J. (2013): Bullying among Jordanian school children, its effects on school performance, and the contribution of general physical and dentofacial features. American Journal of Orthodontics \& Dentofacial Orthopedics. 144 (6). 872-878.

Alika, H. I. (2012): Bullying as a Correlate of Dropout from School among Adolescents in Delta State: Implication for Counselling. Education. 132 (3). 523-531.

Baum, S. (2007, studeni): Cyberbullying: a Virtual Menace. Rad izložen na Nacionalnoj konferenciji protiv nasilja, Melbourne.

Beckman, L., Hagquist, C., Hellström, L. (2013): Discepant gender patterns for cyberbullying and traditional bullying - An analysis of Swedish adolescent data. Computers in Human Behavior. 29 (5). 1896-1903.

Beran, T., Li, Q. (2007): The Relationship between Cyberbullying and School Bullying. Journal of Student Wellbeing. 1 (2). 15-33.

Berne, S., Frisén, A., Kling, J. (2014): Appearance-related cyberbullying: A qualitative investigation of characteristics, content, reason, and effects. Body image. 11 (4). 527-533.

Boel-Studt, S., Renner, L. M. (2014): Child and family-level correlates of direct and indirect peer victimization among children ages 6-9. Child Abuse \& Neglect. 38 (6). 1051-1060.

Bradshaw, C., Waasdorp, T., Goldweber, A., Johnson, S. (2013): Bullies, Gangs, Drugs, and School: Understanding the Overlap and the Role of Ethnicity and Urbanicity. Journal of Youth \& Adolescence. 42 (2). 220-234. 
Burton, A. K., Florell, D., Wygant, D. B. (2013): The Role of Peer Attachment and Normative Beliefs about Aggression on Traditional Bullying and Cyberbullying. Psychology in the Schools. 50 (2). 103-115.

Cassidy, W., Jackson, M., Brown, K. N. (2009): Sticks and Stones Can Break My Bones, But How Can Pixels Hurt Me? Students' Experiences with Cyber-Bullying. School Psychology International. 30 (4). 383-402.

Dehue, F., Bolman, C., Vollink, T., Pouwelse, M. (2012): Cyberbullying and Traditional Bullying in Relation to Adolescents' Perception of Parenting. Journal of CyberTherapy \& Rehabilitation. 5 (1). 25-34.

Delveaux, K. D., Daniels, T. (2000): Children's Social Cognitions: Physically and Relationally Aggressive Strategies and Children's Goals in Peer Conflict Situations. MerrillPalmer Quarterly. 46 (4). 672-692.

Deniz, M. (2015): A Study on Primary School Student's Being Cyber Bullies and Victims According to Gender, Grade, and Socioeconomic Status. Croatian Journal Educational. 17 (3). 659-671.

DeSmet, A., Deforche, B., Hublet, A., Tanghe, A., Stremersch, E., De Bourdeaudhuij, I. (2014): Traditional and cyberbullying victimization as correlates of psychosocial distress and barriers to a healthy lifestyle among severely obese adolescents-a matched case-control study on prevalence and results from a cross sectional study. BMC Public Health. 14 (224). 1-12.

Didden, R., Scholte, R. H., Korziliius, H., de Moor, J. M. H., Vermeulen, A., O'Reilly, M., Lang, R., Lancioni, G. E. (2009): Cyberbullying among students with intellectual and developmental disability in special education settings. Developmental Neurorehabilitation. 12 (3). 146-151.

Dooley, J. J., Pyżalski, J., Cross, D. (2009): Cyberbullying Versus Face-to-Face Bullying: A Theoretical and Conceptual Review. Journal of Psychology. 217 (4). 182-188.

Duggins, S. D., Kuperminc, G. P., Henrich, C. C., Smalls-Glover, C., Perilla, J. L. (2016): Aggression among adolescent victims of school bullying: Protective roles of family and school connectedness. Psychology of Violence. 6 (2). 205-212.

Eden, S., Heiman, T., Olenik-Shemesh, D. (2013): Teachers' perceptions, beliefs and concerns about cyberbullying. British Journal of Educational Technology. 44 (6). 10361052.

Erdur-Baker, Ö. (2010): Cyberbullying and its correlation to traditional bullying, gender and frequent and risky usage of intenet-mediated communication tools. New Media \& Society. 12 (1). 109-125.

Espelage, D. L., Hong, J. S., Rao, M. A., Low, S. (2013): Associations Between Peer Victimization and Academic Performance. Theory Into Practice. 52 (4). 233-240.

Fanti, K. A., Demetriou, A. G., Hawa, V. V. (2012): A longitudinal study of cyberbullying: Examining risk and protective factors. European Journal of Developmental Psychology. 9 (2). 168-181.

Festl, R., Scharkow, M., Quandt, T. (2013): Peer Influence, Internet use and Cyberbullying: A Comparison of Different Context Effects among German Adolescents. Journal of Children \& Media. 7 (4). 446-462. 
Figula, E., Margitics, F., Pauwlik, Z., Szatmári, A. (2011): School bullying: background factors of the victims, bulllies, bully/victims in family socialization. Mentálhigienè ès Psichoszomatika. 12 (1). 47-72.

Floros, G., Paradeisioti, A., Hadjimarcou, M., Mappouras, D. G., Kalakouta, O., Avagianou, P., Siomos, K. (2013): Cyberbullying in cyprus-Associated parenting style and psychopathology. Studies in Health Technology and Informatics. 191. 85-89.

Frisén, A., Berne, S. (2014., svibanj): Appearance related cyberbullying-A problem especially for girls. Rad izložen na Konferenciji: Cyberbullying: A Challenge for Researchers and Practitioners, Gothenbur.

García Fernández, C. M., Romera Félix, E. M., Ortega Ruiz, R. (2015): Explicative factors of face-toface harassment and cyberbullying in a sample of primary students. Psicothema. 27 (4). 347-353.

Georgiou, S. (2008): Parental style and child bullying and victimization experiences at school. Social Psychology of Education. 11 (3). 213-227.

Georgiou, S., Fousiani, K., Michaelides, M., Stavrinides, P. (2013): Cultural value orientation and authoritarian parenting as parameters of bullying and victimization at school. International Journal of Psychology. 48 (1). 69-78.

Gómez-Ortiz, O., Romera, E. M., Ortega-Ruiz, R. (2015): Parenting styles and bullying. The mediating role of parental psychological aggression and physical punishment. Child Abuse \& Neglect. DOI: 10.1016/j.chiabu.2015.10.025.

Good, B., Fang, L. (2015): Promoting Smart and Safe Internet Use Among Children with Neurodevelopmental Disorders and Their Parents. Clinical Social Work Journal. 43 (2). 179-188.

Greene, M. B. (2006): Bullying in Schools: A Plea for Measure of Human Rights. Journal of Social Issues. 6 (1). 63-79.

Griezel, L., Finger, L. R., Bodkin-Andrews, G. H., Craven, R. G., Yeung, A. S. (2012): Uncovering the Structure of and Gender and Developmental Differences in Cyber Bullying. Journal of Educational Research. 105 (6). 442-455.

Heiman, T., Olenik-Shemesh, D. (2015): Cyberbullying Experience and Gender Differences Among Adolescents in Different Educational Settings. Journal of Learning Disabilities. 48 (2). 146-155.

Heirman, W., Walrave, M. (2008): Assessing Concerns and Issues about the Mediation of Technology in Cyberbullying. Cyberpsychology: Journal of Psychosocial Research on Cyberspace. 2 (2). 1-18.

Hemphill, S. A., Heerde, J. A. (2014): Adolescent Predictors of Young Adult Cyberbullying Perpetration. Journal of Adolescent Health. 55 (4). 580-587.

Hemphill, S. A., Tollit, M., Kotevski, A., Heerde, J. A. (2014): Predictors of Traditional and CyberBullying Victimization: A Longitudinal Study of Australian Secondary School Students. Journal of Interpersonal Violence. 30 (15). 1-24.

Hepler, J. B. (1997): Social Development of Children: The Role of Peers. Children \& Schools. 19 (4). 242-256.

Holmberg, K., Hjern, A. (2008): Bullying and attention-deficit-hyperactivity disorder in 10-yearolds in a Swedish community. Developmental Medicine \& Child Neurology. 50 (2). 134-138. 
Janssen, I., Craig, W. M., Boyce, W. F., Pickett, W. (2004): Associations Between Overweight and Obesity With Bullying Behaviors in School-Aged Children. Pediatrics. 113 (5). 11871194.

Karlsson, E., Stickley, A., Lindblad, F., Schwab-Stone, M., Ruchkin, V. (2014): Risk and protective factors for peer victimization: a 1-year follow up study of urban American students. European Child \& Adolescent Psychiatry. 23 (9). 773-781.

Khamis, V. (2015): Bullying among school-age children in the greater Beirut area: Risk and protective factors. Child Abuse \& Neglect. 39. 137-146.

Kowalski, R. M., Limber, S. P. (2007): Electronic Bullying Among Middle School Students. Journal of Adolescent Health. 41 (6). 22-30.

Kowalski, R. M., Limber, S. P. (2013): Psychological, Physical, and Academic Correlates of Cyberbullying and Traditional Bullying. Journal of Adolescent Health. 53 (1). 13-20.

Krmek, M., Buljan Flander, G., Hrpka, H. (2007): Nasilje među vršnjacima Internetom. U Kolesarić V. (ur.), Psihologija i nasilje u suvremenom društvu. Osijek: Sveučilište Josipa Jurja Strossmayera, Filozofski fakultet. 125-132.

Kukaswadia, A. A. (2009): Social Consequences of Obesity among Canadian Youth. Doktorska disertacija. Kingston. Ontario: Queen's University.

Levine, E. L. (2013): A Study of Parental Understanding of and Intervention in Cyberbullying among Children in Fourth through Eight Grade. Doktorska disertacija. Indiana. University of Pennsylvania.

Li, Q. (2005): New bottle but old wine: A research of cyberbullying in schools. Computers in Human Behavior. 23 (4). 1777-1791.

Li, Q. (2006): Cyberbullying in Schools: A Research of Gender Differences. School Psychology International. 27 (2). 157-170.

Liau, A. K., Khoo, A., Ang P. H. (2008): Parental Awareness and Monitoring of Adolescent Internet Use. Current psychology. 27 (4). 217-233.

Lösel, F., Bender, D. (2013): Aggressive, Delinquent, and Violent Outcomes of School Bullying: Do Family and Individual Factors Have a Protective Function?. Journal of School Violence. 13 (1). 59-79.

Lösel, F., Farrington, D. P. (2012): Direct Protective and Buffering Protective Factors in the Development of Youth Violence. American Journal of Preventive Medicine. 43 (2). 8-23.

Ma, L., Phelps, E., Lerner, J. V., Lerner, R. M. (2009): The development of academic competence among adolescents who bully and who are bullied. Journal of Applied Developmental Psychology. 30 (5). 628-644.

Magin, P. (2013): Appereance-related bullying and skin disorders. Psychodermatology. 31 (1). 66-71.

Makri-Botsari, E., Karagianni, G. (2014): Cyberbullying in Greek Adolescents: The Role of Parents. Procedia - Social and Behavioral Sciences. 116. 3241-3253.

Mehari, K. R., Farell, A. D., Le, A. T. H. (2014): Cyberbullying Among Adolescents: Measures in Search of a Construct. Psychology of Violence. 4 (4). 399-415.

Menesini, E., Nocentini, A. (2009): Cyberbullying definition and measurement: Some critical considerations. Journal of Psychology. 217 (4). 230-232. 
Milašin, A., Vranić, T., Buljubašić Kuzmanović, V. (2009): Ispitivanje učestalosti verbalne agresije kod djece i mladeži. Život i škola. 55 (22). 116-141.

Mitchell, M. S. (2011): Cyberbullying and Academic Achievement: Research into the Rates of Incidence, Knowledge of Consequences, and Behavioral Patterns of Cyberbullying. Doktorska disertacija. University of Connecticut.

Modecki, K. L., Minchin, J., Harbaugh, A. G., Guerra, N. G., Runions, K. C. (2014): Bullying Prevalence Across Contexts: A Meta-analysis Measuring Cyber and Traditional Bullying. Journal of Adolescent Health. 55 (5). $602-611$.

Olweus, D. (1998): Nasilje među djecom u školi. Zagreb. Školska knjiga.

Patchin, J. W., Hinduja, S. (2015): Measuring cyberbullying: Implications for research. Aggression and Violent Behavior. 23. 69-74.

Pećnik, N., Tokić, A. (2011): Roditelji i djeca na pragu adolescencije: pogled iz tri kuta, izazovi i podrška. Ministarstvo obitelji, branitelja i međugeneracijske solidarnosti, Zagreb.

Peluchette, J. V., Karl, K., Wood, C., Williams, J. (2015): Cyberbullying victimization: Do victims' personality and risky social network behaviors contribute to the problem?. Computers in Human Behavior. 52. 424-435.

Pezo, A. (2010): Uloga odraslih u zaštiti djece na Internetu. U Jelavić M. (ur.), Dječja prava i slobodno vrijeme. Pravobranitelj za djecu, Zagreb. 79-86.

Pregrad, J., Tomić Latinac, M., Mikulić, M., Šeparović, N. (2010): Iskustva i stavovi djece, roditelja i učitelja prema elektroničkim medijima. Ured UNICEF-a za Hrvatsku, Zagreb.

Puzić, S., Baranović, B., Doolan, K. (2011): Školska klima i sukobi u školi. Sociologija i prostor. 49 (3). 335-358.

Rajhvajn Bulat, L., Ajduković, M. (2012): Obiteljske i psihosocijalne odrednice vršnjačkoga nasilja među mladima. Psihologijske teme. 21 (1). 167-194.

Riebel, J., Jäger, R. S., Fischer, U. C. (2009): Cyberbullying in Germany- an exploration of prevalence, overlapping with real life bullying and coping strategies. Psychology Science Quarterly. 51 (3). 298-314.

Ryan, K. N., Curwen, T. (2013): Cyber-Victimized Students: Incidence, Impact, and Intervention. SAGE Open. 3 (4). 1-7.

Sapouna, M., Wolke, D. (2013): Resilience to bullying victimization: The role of individual, family and peer characteristics. Child Abuse \& Neglect. 37 (11). 1-10.

Schroeder, J., Cappadocia, M., Bebko, J., Pepler, D., Weiss, J. (2014): Shedding Light on a Pervasive Problem: A Review of Research on Bullying Experiences Among Children with Autism Spectrum. Journal of Autism \& Developmental Disorders. 44 (7). 15201534.

Selak Bagarić, E., Buljan Flander, G., Hrpka, H., Tomić, J., Bilić, V. (2014., studeni): Uloga podržavajuće školske klime u prevenciji elektroničkog nasilja. Rad izložen na XXII. Godišnjoj konferenciji hrvatskih psihologa: Kako obrazovanju dodati boju? - uloga i izazovi za psihologe, Rovinj.

Shariff, S., Gouin, R. (2006): Cyber-Dilemmas: Gendered Hierarchies, New Technologies and Cyber-Safety in Schools. Atlantis. 31 (1). 27-37. 
Shetgiri, R., Lin, H., Flores, G: (2013). Trends in risk and protective factors for child bullying perpetration in the United States. Child Psychiatry \& Human Development. 44 (1), 89-104.

Silva, M. A. I., Pereira, B., Mendonça, D., Nunes, B., Oliveira, W. A. (2013): The Involvement of Girls and Boys with Bullying: An Analysis of Gender Differences. International Journal of Environmental Research and Public Health. 10 (12). 6820-6831.

Slonje, R., Smith, P. K. (2008): Cyberbullying: Another main type of bullying?. Scandinavian Journal of Psychology. 49 (2). 147-154.

Slonje, R., Smith P. K., Frisen, A. (2012): The nature of cyberbullying, and strategies for prevention. Computers in Human Behavior. 29 (1). 26-32.

Smith, P. K., Mahdavi, J., Carvalho, M., Fisher, S., Shanette, R., Tippett, N. (2008): Cyberbullying: Its Nature and Impact in Secondary School Pupils. Journal of Child Psychology and Psychiatry. 49 (4). 376-385.

Stattin, H., Kerr, M. (2000): Parental monitoring: a reinterpretation. Child Development. 71 (4). 1072-1085.

Taylor, L. A., Saylor, C., Twyman, K., Macias, M. (2010): Adding insult to injury: bullying experiences of youth with attention deficit hyperactivity disorder. Children's Health Care. 39 (1). 59-72.

Ttofi, M. M., Farrington, D. P. (2011): Effectiveness of school-based programs to reduce bullying: a systematic and meta-analytic review. Journal of Experimental Criminology. 7 (1). 27-56.

Twyman, K., Saylor, C., Taylor, L. A., Comeaux, C. (2010): Comparing Children and Adolescents Engaged in Cyberbullying to Matched Peers. Cyberpsychology, Behavior, and Social Networking. 13 (2). 195-199.

Van der Werf, C. (2014): The Effects of Bullying on Academic Achievement. Desarrollo y Sociedad. 74. 278-308.

Vandebosch, H., Poels, K., Deboutte, G. (2014): Schools and Cyberbullying: Problem Perception, Current Actions and Future Needs. International Journal of Cyber Society and Education. 7 (1). 29-48.

Vandebosch, H., Van Cleemput, K. (2008): Defining Cyberbullying: A Qualitative Research into the Perceptions of Youngsters. Cyberpsychology \& Behavior, 11(4), 499-503.

Velki, T., Kuterovac Jagodić, G. (2014): Individualni i kontekstualni činitelji dječjega nasilničkoga ponašanja prema vršnjacima. Ljetopis socijalnog rada. 21 (1). 33-64.

Velki, T., Ozdanovac, K. (2014): Preventivni programi usmjereni na smanjenje vršnjačkog nasilja u osnovnim školama na području Osječko-baranjske županije. Školski vjesnik-Časopis za pedagogijsku teoriju i praksu. 63 (3). 327-352.

Velki, T., Vrdoljak, G. (2013): Uloga nekih vršnjačkih i školskih varijabli u predviđanju vršnjačkoga nasilnog ponašanja. Društvena istraživanja. 22 (1). 101-120.

Wachs, S. (2012): Moral disengagement and emotional and social difficulties in bullying and cyberbullying: differences by participant role. Emotional and Behavioural Difficulties. 17 (3-4). 347-360.

Wachs, S., Wolf, K. D., Pan, C. (2012): Cybergrooming: Risk factors, coping strategies and associations with cyberbullying. Psicothema. 24 (4). 628-633. 
Wang, J., lannotti, R. J., Nansel, T. R. (2009): School Bullying Among Adolescents in the United States: Physical, Verbal, Relational, and Cyber. Journal of Adolescent Health. 45 (4). 368-375.

Wang, R., Bianchi, S. M., Raley, S. B. (2005): Teenagers' Internet Use and Family Rules: A Research Note. Journal of Marriage and Family. 65 (5). 1249-1258.

Willard, N. (2007): Cyberbullying and Cyberthreats: Responding to the Challenge of Online Social Aggression, Threats and Distress. Champaign. Research Press.

Wong, D. S. W., Chan, H. C. O., Cheng, C. H. K. (2014): Cyberbullying perpetration and victimization among adolescents in Hong Kong. Children andYouth Serveces Review. 36. 133-140.

Yen, C., Chou, W., Liu, T., Ko, C., Yang, P., Hu, H. (2014): Cyberbullying among male adolescents with attention-deficit/hyperactivity disorder: Prevalence, correlates, and association with poor mental health status. Research in Developmental Disabilites. 35 (12). 3543-3553.

You, S., Kim, E., Kim, M. (2014): An Ecological Approach to Bullying in Korean Adolescents. Journal of Pacific Rim Psychology. 8 (1). 1-10. 